\title{
The United States Supreme Court Landmark Cases: Implications on Racial/Ethnic Minorities' Welfare
}

\author{
Silas Mutie Nzuva
}

\begin{abstract}
Essentially, the United States Supreme Court plays a critical role in setting precedents that are followed by lower federal courts and state courts. This implies that faulty decision by the Supreme Court has a ripple effect, characterized by adversities in the delivery of justice across the board. Over the years, the United States Supreme Court has made various landmark rulings, some of which have been regarded as the worst decisions ever, while others have been deemed exemplary. From the 1900s and to around the mid-1900s, the United States Supreme Court made various rulings, the majority of which touched on racial segregation and discrimination of ethnic minorities. The rulings set critical precedence and gave guidelines to states with respect to the formulation and implementation of state laws. Understanding such rulings can greatly shed light regarding the historical background of the United States judicial system and what can be done to foster justice and equality in the future. This study entailed a qualitative content analysis research design to study and analyze six main cases: Pace $v$. Alabama (1883), Dred Scott v. Sandford (1856), Loving v. Virginia (1967), Plessy v. Ferguson (1896), Brown v. Board of Education, Topeka, Kansas (1954-55) and Ozawa v. United States (1922). The results of the content analysis are presented. The content analysis is based on the statements and their implicit messages.
\end{abstract}

Keywords: The United States Supreme Court landmark cases, racial discrimination, ethnicity, racial profiling, landmark court decisions, U.S historical cases.

DOI: $10.7176 / \mathrm{JLPG} / 110-03$

Publication date:June $30^{\text {th }} 2021$

\section{Introduction}

The impetus of this study is to analyze through content analysis the impact on racial/ethnic minorities of Landmark United States Supreme Court cases, and specifically, Pace v. Alabama (1883), Dred Scott v. Sandford (1856), Loving v. Virginia (1967), Plessy v. Ferguson (1896), Brown v. Board of Education, Topeka, Kansas (1954-55) and Ozawa v. United States (1922). Content analysis is an analytical approach employed in the analysis of communication content in social science. In this study, content analysis aided in bringing out themes and patterns in the above-mentioned case rulings of the Supreme Court in an effort to answer the research question. Earl Babbie defines it as "the study of recorded human communications, such as books, websites, paintings, and laws" [3]. This study is based on a content analysis of the most significant statements and themes that emerge from the legal cases, which support the lasting legacy of discrimination and racial/ethnic inequalities in the Criminal Justice System.

Racism is a phenomenon that had dominated the United States' socio-economic and political systems for decades, characterized by the existence of racial inequalities, discrimination, and sidelining of ethnic minorities in governance matters [33]. While various statutes and reforms in the judicial system have been done in an effort to eliminate discriminations of all kinds, the latter still remains persistent in some social facets. After the American civil war, various amendments were enacted in the United States to reconstruct the constitution and advocate for equal treatment of all American citizens. Some of the iconic amendments in the United States Constitution entailed the thirteenth amendment, which aimed at alleviating slavery and involuntary servitude in the American society, the fourteenth amendment, which focused on eliminating all laws that fostered racial segregation and promoting equal treatment of all the American citizens [35], and the fifteenth amendment, which gave the African American men the right to vote in addition to banning any prohibition of such rights by the states on the basis of skin color or servitude condition [25].

The institution of slavery is as old as civilization. Many nations and empires were built by the muscles of slaves. Slavery was based on the demand and supply of labor. The first Africans were brought to what is now the United States in 1619. In colonial America, most Africans and some white Europeans were indentured servants. During the period 1650-1700, the tobacco plantations in Virginia needed a steady supply of labor, and slavery was the solution. As a result, the African Americans came involuntarily, unlike other European immigrants. Today, African Americans are the second-largest racial minority group in the United States of America.

Alexis de Tocqueville, a French magistrate, in his classic book, Democracy in America, asked President John Quincy Adams: "Do you look at slavery as a great plague for the United States?" "Yes, certainly," Adams answered. "That is the root of almost all the troubles of the present and the fears for the future" [48]. Adams' observations are prophetic. Since the 17th century, through American slavery, emancipation, segregation, and the modern civil rights movement, the issue of race and ethnic relations have been salient. 


\subsection{Research Questions}

Is there an implicit/explicit message of discrimination and racism in the United States Supreme Court cases under examination?

\section{Literature Review}

Over the years, the Supreme Court has made various landmark rulings, which have set critical precedence in the American judicial system. This section presents a review of some of the critical landmark cases that were linked to racial segregation, servitude, and executive orders that instituted curfews and held some ethnic minorities in internment camps. Specifically, the review takes into account the case of Pace v. Alabama, Dred Scott $v$. Sandford, Plessy v. Ferguson, Civil Rights Cases, Cumming v. Richmond County Bd. of Ed, The United States v. Bhagat Singh Thind, Ozawa v. the United States, Gong Lum v. Rice, Powell v. Alabama, Hirabayashi v. the United States and Korematsu v. the United States. A theoretical framework is also presented at the end of the section.

\subsection{Pace v. Alabama, 106 U.S. 583, 1 S. Ct. 637, 27 L. Ed. 207 (1883)}

In this aces, Mary J. Cox, a white woman, and Tony Pace, a Negro, were both sentenced to two years in prison for violating the sec. 4189 of the Alabama laws. According to the case, the two engaged in an act that amounted to "living together in a state of adultery or fornication." According to Novkov, racial intermarriages, specifically between white persons and ethnic minorities, were prohibited under Section 4184 of the Code of Alabama [36]. Wallenstein explains that the main reason as to why it was a criminal offense to engage in fornication, adulatory, or intermarriage with someone from a different race was not because it was morally wrong, but because the whites wished to maintain their purity and dominance in the United States [45]. The Supreme Court affirmed the circuit court of Alabama's rulings and rejected the plaintiff's claims that the indictment violated the fourteenth amendment, which banned the states from denial of any person equal protection, irrespective of their racial affiliation. The court further asserted that both parties were equally punished, and hence there was no issue of discrimination or inequality in the punishment. However, Novkov explains that this ruling implicitly promoted racial segregation and inequality by deterring future intermingling of the two races [36]. This is because the main question was not whether the individuals were treated equally but why the interaction was prohibited. According to Wallenstein, while the punishment may not have been direct discrimination, it triggered racial segregation by prohibiting intermarriage with ethnic minorities, hence promoting the dominance of the white culture and thwarting any social constructs that could abridge the two races and steer social acceptance of one another [45].

\subsection{Dred Scott v. Sandford, 60 U.S. 393, 15 L. Ed. 691, 15 L. Ed. $2 d 691$ (1857)}

Dred was a slave whose master was Dr. Emerson. During his slavery, Dr. Emerson moved from Missouri, a legalized slave state, to Illinois and later Louisiana; both states were free states. According to chief justice Taney during the Supreme Court ruling, the laws of Missouri applied since it was the state where he resided when he decided to sue for freedom and recognition as a citizen [14]. Irrespective of whether the plaintiff had lived in Free states such as Illinois, Missouri was still considered a slave state, as depicted in the Missouri Compromise. Farber explains that this was a critical oversight by the Supreme Court, as it is tasked with the responsibility of ensuring that the laws in question are capable of delivering justice impartiality [14]. In line with this, Chambers Jr holds it that the justices knew or ought to have known that by adopting the laws of a slave state in the interpretation of the case, they denied Dred his rights as such states did not consider the slaves as citizens and further, slaves were perceived to be the property of the masters [11]. Graber posits that the Supreme Court and the justices should be the custodian of the law and always strike a balance where the different statutes conflict [19].

\subsection{Plessy v. Ferguson, 163 U.S. 537, 16 S. Ct. 1138, 41 L. Ed. 256 (1896)}

In this case, the United States Supreme Court established the constitutionality of racial segregation on the use of public facilities such as schools, hospitals, and transport systems as long as the separation facilities were equal. This ruling supported the separate but equal doctrine and legitimization of the racial separation laws. As such, rather than serving to promote equality among the ethnic minorities, it served to widen the rift between the whites and ethnic minorities, in addition to steering discrimination. Medley explains that having been slaves for a substantial period, the ethnic minorities were disadvantaged in social, economic, political, and technological facets [32]. Hence, they lacked the necessary strategies and resources to ensure that they were equally treated. The legalization of racial segregation by the Supreme Court, therefore, placed the ethnic minorities at a greater disadvantage and denied them any legal infrastructure that they could use to regain equal treatment. Having been the dominant group for decades, the whites dominated the economic, social, and political facets and separate but equal doctrine implied forgoing some of the privileges for the black communities; this was literally impossible in light of the racial segregation fostered by the American judicial system [17]. 


\subsection{Civil Rights Cases, 109 U.S. 3, 3 S. Ct. 18,27 L. Ed. 835 (Supreme Court 1883)}

These were a combination of five cases that sought the intervention of the Supreme Court under the $14^{\text {th }}$ amendment to ban racial segregation in the public transportation system, hospitals, schools, and other public facilities that were tagged "whites only." Eisenberg explains that while the American civil war was a critical phase in the United States' reconstruction and recognition of the ethnic minorities as citizens, three were various challenges faced in the American judicial system, characterized by deviance from the enacted laws [13]. The Supreme Court, however, rejected the claims by the plaintiffs and subsequently declared the Civil Rights Act of 1875 unconstitutional. The nullification of the act supported the Jim Crow laws, which upheld racial segregation, and perpetrated the discrimination of the ethnic minorities. Lado posits that the Civil Rights Act of 1875 promoted the equal treatment of ethnic minorities and banned racial segregation as well as the state laws that harbored servitude, racial segregation, and discrimination [27]. The striking down of this act resulted in an era that was filled with racial separation and discrimination of minorities in the use of public facilities. Further, the Supreme Court also asserted that the existence of uncodified discrimination did not infringe the $13^{\text {th }}$ amendment and 14th amendment, and hence it could not be constitutionally prohibited. According to Weaver, the $13^{\text {th }}$ amendment had banned slavery and the existence of such state laws, while the $14^{\text {th }}$ amendment advocated for equal protection of all Americans irrespective of their racial affiliation [46].

\subsection{Cumming v. Richmond County Bd. of Ed., 175 U.S. 528, 20 S. Ct. 197, 44 L. Ed. 262 (1899)}

In this case, Cumming, the plaintiff, filed a lawsuit claiming that the county board of education used the $\$ 45,000$ tax made for primary, intermediate, and high school to only support the education of the whites and did not provide equal facilities for the ethnic minorities. According to the facts of the case, the Richmond board of education had temporarily suspended the colored people and was using the collected educational taxes to only sponsor the schools for the whites. The state court did not find any problem with temporal suspension of the back school and, likewise, maintenance of the existing schools forth the whites, and as a result, Cummings claims were rejected [12]. The same ruling was affirmed by the Supreme Court when the plaintiff filed an appeal in the United States Supreme Court. Whether the county was experiencing harsh economic times or not, it was not right for the education of the colored children to be temporarily suspended. According to the $14^{\text {th }}$ amendment, every American citizen deserved equal treatment; hence, fair and equal treatment would have entailed temporary suspension for both the white schools and schools for the colored people [12]. Further, the Supreme Court also explained that the number of white children was more than that of the colored population, and the county did not have sufficient resources to educate every child. The Supreme Court rulings also depicted its denial of having jurisdiction over decisions over the state courts [6].

\subsection{United States v. Bhagat Singh Thind, 261 U.S. 204, 43 S. Ct. 338, 67 L. Ed. 616 (1923)}

This case was based on the United States naturalization act of 1906, whereby citizenship through naturalization was only allowed for "free white persons" as well as people of African descent. As such, other ethnic minorities were denied a chance to become citizens of the United States through naturalization. In this case, the United States Supreme Court found Thind to be racially ineligible for United States citizenship. From the material facts presented, Thind was an Indian Sikh of the caste Aryan bloodline. Since the plaintiff was excluded by the Naturalization Act of 1906 from seeking citizenship as an ethnic minority of another tribe other than African, he argued that his Caste Aryan ancestry was technically white, and hence should be classified as a "free white person" [4]. The plaintiff argued that that whites are Europeans and European Americans, and northern Indians share a common ancestry and are indeed Indo-European peoples. In deciding this case, the core consideration of the court was the purity of his acclaimed tribe with respect to being white. Snow challenges this ideology and asserts that citizenship by naturalization should not be awarded on the basis of bloodline purity or race but rather the character and the duration that an individual has lived in the country and the willingness to be a patriotic citizen [43]. In its rulings, the Supreme Court denied Thind citizenship, claiming that through the Caste Aryan ancestry, he could not be regarded as a citizen and that the term "white persons" only referred to the Caucasians only.

\subsection{Ozawa v. the United States, 260 U.S. 178, 43 S. Ct. 65, 67 L. Ed. 199 (1922)}

In this case, Ozawa, a Japanese male who had lived in the United States for over 20 years, was denied citizenship based on the naturalization act of 1906, which only granted citizenship by naturalization to free white people and individuals of African origin [40]. Ozawa argues that the Japanese were whites and hence should be considered as a free white person and be granted American citizenship. Apparently, his claims were denied on the ground that free white persons referred to only Caucasians and not any other type of white person. As such, the Supreme Court perceived the Japanese not to be "free white persons" within the meaning of the constitutional provisions. Ichioka notes that it is the duty of the Supreme Court to note any shortcomings of the existing law and make the necessary recommendations for the adjustment [23]. It is clear that the United States Naturalization Act of 1906 
that was relied on by the Supreme Court in making citizenship-related verdicts was impaired, and changes were required to ensure other ethnic minorities too could seek citizenship in the United States. However, the Supreme Court failed in its duty and aided in propagating facial inequality and suppression of ethnic minorities.

\subsection{Gong Lum v. Rice, 275 U.S. 78, 48 S. Ct. 91, 72 L. Ed. 172 (1927)}

This is yet another case in which the United States Supreme Court prohibited Martha Lum, a child of Chinese descent, from attending a white school, by asserting that she did not qualify as a white person and hence could not attend a white school [9]. Based on material facts present in the court, Gong Lum, the father of Martha Lum, was a tax-paying resident of Mississippi State. Having been born in the United States, Martha was a native U.S citizen; however, after her first day in the all-white Rosedale Consolidated School, she was banned from proceeding with the education at the school. The school board of trustees argued that she was of Chinese decency and not Caucasian; hence, she could not enjoy the privileges of the whites. Upon filing a lawsuit, a mandamus order was filed by the Mississippi trial court, ordering the school board to readmit her. The case found its way to the Supreme Court of Mississippi, which overturned the trial court decision, claiming that Martha was of a yellow or Mongolian race and could not be considered as white, despite her being a native citizen. The United States Supreme Court ruled that the fourteenth amendment was not violated by exclusion on account of race in the use of public facilities [47].

\subsection{Powell v. Alabama, 287 U.S. 45 (1932)}

This was one of the landmark cases in the United States that aided in doing away with ignorance and deviation of the courts of law in following the due processes stipulated in the constitution. The Supreme Court overturned a conviction against nine young black men. Based on the material facts, it had earlier been claimed that the black men had raped two women of white descent. The 9 men had not been accorded the due process of the law, and neither did they have access to an attorney to represent them. According to Mayeux, in a court of law, any accused person is innocent unless otherwise proven guilty and must always be provided with the right to an attorney [31]. The state should as well provide an attorney in case an individual is incapable of getting one. The Supreme Court found the prior trial of Powel to have violated the United States Bill of Rights, which holds that any trial in a court of law must uphold the relevant criminal procedural provision. According to the Supreme Court, the conviction of the 9 had also violated both the $14^{\text {th }}$ amendment and the $6^{\text {th }}$ amendment, which affirm the right to counsel for any individual being tried. According to Carter, the reversal of Powell vs. Alabama aided in affirming the federal rules and making it legally binding to follow the due process of the law when convicting an individual [8]. This, in turn, did set critical precedence for the state courts lower federal courts to be sure that their ruling was in line with the law.

\subsection{Hirabayashi v. the United States, 320 U.S. 81, 63 S. Ct. 1375, 87 L. Ed. 1774 (1943).}

In this case, the United States Supreme Court found it constitutional for Executive Order 9066 to impose curfews on ethnic minorities. According to the Supreme Court ruling, the executive order, which applied curfews and placed individuals affiliated to the opponent countries in internment camps during the war, was constitutional, as the need to protect the country against espionage and attacks outweighed the individual rights by citizens with organs to such countries. This executive order was issued during World War II and saw the imposition of restrictions and curfew against the Japanese Americans before being taken to internment camps. Segal explains that tough the Supreme Court supported the executive order, it was in violation of the $14^{\text {th }}$ amendment, which sought protection and equality among all American citizens irrespective of their racial affiliation [41]. Nakanishi explains that there was no sure way that the Japanese Americans should have participated in espionage, being American citizens, as the majority had sought American citizenship without intentions of returning back to their native land [34].

\subsection{Korematsu v. the United States, 323 U.S. 214, 65 S. Ct. 193, 89 L. Ed. 194 (1944)}

This was a controversial case ruling by the United States Supreme Court, which found Executive Order 9066 to be constitutional. Nakanishi explains that the executive order restricted Japanese Americans to Internment camps during World War II [34]. The executive order was executed regardless of the citizenship of the individual, provided that one was racially affiliated to Japan. Essentially, while the court claimed to have acted on the best in tests of the American citizens, validating the continuity of the executive order seemed to propagate ethnic oppression and discrimination. In the ruling, the court held that the protection of the United States as a country outweighs the rights of the American citizens of Japanese descent. According to Nakanishi, this brings the question of the extent to which the rights of ethnic minorities are protected and whether the same would have been done for the whites [34]. 


\section{Theoretical Framework}

This study adopts three main theoretical approaches: the functionalist perspective, labeling approach, and critical theory

\subsection{Functionalist Perspective.}

Emphasizes how the parts of society are structured to maintain its stability. As such, it entails the maintenance of the status quo and upholds conservative orientation. This perspective propagates the belief that racist ideologies provide a moral justification for maintaining a stratified society. Racist beliefs relieve the dominant group of the responsibility to address the economic and educational problems faced by subordinate groups.

\subsection{Labeling Approach}

This theoretical approach propagated by scholars such as Howard Becker, and which explains why certain people are viewed as deviants and others engaging in the same behavior are not. For instance, stereotypes are exaggerated generalizations about all members of a group. When applied by people in power, it can have negative consequences for the falsely identified group.

\subsection{Critical Race Theory (CRT)}

This theory emphasizes that race lies at the very nexus of American life; as such, a relationship exists between race, the justice system, and society [28]. Therefore, it is linked to the development of African American thought in the post-civil rights era. CRT theorists and legal scholars challenge the aforementioned classical theories and conservative civil rights stance of the colorblind approach to social justice. Critical Race Theory can, therefore, be used in the analysis of the inequalities in the criminal justice system.

\section{Methods}

The research methodology is very critical as it outlines the approach, procedure, and methods that the researcher used. This section presents the research design, the data collection methods, and the data reduction techniques that the researcher employed in order to satisfactorily answer the research question presented in section 1 of this research paper.

\subsection{Research Design}

In order to answer the research question presented in section 1 of this research paper, the researcher used qualitative content analysis for the collection and analysis of data. Essentially, content analysis can be carried out using two approaches; conceptual analysis and relational analyses. The conceptual analysis entails establishing the existence and frequency of concepts in a given text. On the other hand, relational analysis entails the examination of the given content to outset the relationship between the different concepts. The researcher used both conceptual and relational approaches of content analysis with respect to the most significant statements and themes on the following Landmark Supreme Court cases:

1. Pace v. Alabama, 106 U.S. 583, 1 S. Ct. 637, 27 L. Ed. 207 (1883).

2. Loving v. Virginia, 388 U.S. 1, 87 S. Ct. 1817, 18 L. Ed. 2d 1010 (1967).

3. Dred Scott v. Sandford, 60 U.S. 393, 15 L. Ed. 691, 15 L. Ed. 2 d 691 (1857).

4. Plessy v. Ferguson, 163 U.S. 537, 16 S. Ct. 1138, 41 L. Ed. 256 (1896).

5. Brown v. Board of Education, 347 U.S. 483, 74 S. Ct. 686, 98 L. Ed. 873 (1954).

6. Ozawa v. the United States, 260 U.S. 178, 43 S. Ct. 65, 67 L. Ed. 199 (1922).

\subsection{Data Collection}

The data was collected from six Landmark Supreme Court cases: Pace v. Alabama (1883), Loving v. Virginia (1967), Dred Scott v. Sandford (1857), Plessy v. Ferguson (1896), Brown v. Board of Education (1954), and Ozawa v. United States (1922). After reading each case thoroughly, statements of significant importance were selected. The results were then put into tables for further comparison.

\subsection{Data Reduction}

The researcher read 20 statements on each legal case and noted at least three to five most significant statements that are either favorable or unfavorable with respect to racial inequalities, discrimination, and racism. The findings are presented in the following section.

\section{Results}

This section presents a critical analysis of the Supreme Court cases selected for the study, which include Pace $v$. Alabama (1883), Dred Scott v. Sandford (1856), Loving v. Virginia (1967), Plessy v. Ferguson (1896), Brown v. Board of Education, Topeka, Kansas (1954-55) and Ozawa v. United States (1922). The content analysis is 
based on the statements and their implicit messages (themes), favorable or unfavorable on race/ethnic relations, such as discrimination and racism. The statements are presented in a table format on each case.

Table 1: Pace v. Alabama, 106 U.S. 583, 1 S. Ct. 637, 27 L. Ed. 207 (1883).

\begin{tabular}{|r|l|}
\hline 1. & $\begin{array}{l}\text { Section } 4184 \text { of the Code of Alabama (A provision used as the basis for the ruling): "If any white } \\
\text { person and a colored person shall go out of this State, for the purpose of being married, and with the } \\
\text { intention of returning, and be married out of it, and afterward return to and reside in it, cohabiting as } \\
\text { man and wife, they shall be punished as provided in } \S 20-59, \text { and the marriage shall be governed by the } \\
\text { same law as if it had been solemnized in this State." }\end{array}$ \\
\hline 2. & $\begin{array}{l}\text { Section } 4189 \text { of the Code of Alabama (A provision used as the basis for the ruling): "If any white } \\
\text { person intermarry with a colored person, or any colored person intermarry with a white person, he shall } \\
\text { be guilty of a felony and shall be punished by confinement in the penitentiary for not less than one nor } \\
\text { more than five years" }\end{array}$ \\
\hline 3. & $\begin{array}{l}\text { "Whatever discrimination is made in the punishment prescribed in the two sections is directed against } \\
\text { the offense designated, and not against the person of any particular color or race." }\end{array}$ \\
\hline
\end{tabular}

Mary J. Cox (White) and Tony Pace (Black) were indicted by the Supreme Court under the Alabama Code Section 4184 and 4189, which strictly prohibited fornication, adultery, and intermarriage between the whites and the blacks. According to Section 4189 of the Alabama Code, individuals who committed the above-mentioned crime were to face imprisonment in penitentiary above not exceeding a maximum of 7 years and not below a minimum of two years or be subjected to hard labor. The main question that pops up in Pace v. Alabama is whether the government was right in prohibiting intermarriage between whites and blacks. Of interest is the fact that the aforementioned sections do not just prohibit intermarriage but rather intermarriage with black persons.

Table 2: Loving v. Virginia, 388 U.S. 1, 87 S. Ct. 1817, 18 L. Ed. 2d 1010 (1967).

\begin{tabular}{|c|c|}
\hline & Statements \\
\hline 1. & $\begin{array}{l}\text { "These statutes ( } \$ 258 \text { and } 259 \text { of the Virginia Code) also deprive the Lovings of liberty without due } \\
\text { process of law in violation of the Due Process Clause of the Fourteenth Amendment." }\end{array}$ \\
\hline 2. & $\begin{array}{l}\text { "The freedom to marry has long been recognized as one of the vital personal rights essential to the } \\
\text { orderly pursuit of happiness by free men." }\end{array}$ \\
\hline 3. & $\begin{array}{l}\text { "The fact that Virginia prohibits only interracial marriages involving white persons demonstrates that } \\
\text { the racial classifications must stand on their own justification, as measures designed to maintain White } \\
\text { Supremacy." }\end{array}$ \\
\hline 4. & $\begin{array}{l}\text { "There can be no doubt that restricting the freedom to marry solely because of racial classifications } \\
\text { violates the central meaning of the Equal Protection Clause." }\end{array}$ \\
\hline 5. & $\begin{array}{l}\text { "The Fourteenth Amendment requires that the freedom of choice marry not be restricted by invidious } \\
\text { racial discriminations. Under our Constitution, the freedom to marry, or not marry, a person of another } \\
\text { race resides with the individual, and cannot be infringed by the State." }\end{array}$ \\
\hline
\end{tabular}

This was a landmark ruling by the United States Supreme Court, as it did strike down all the state laws that prohibited interracial marriages and interracial intimate relationships. According to the United States Supreme Court, the prohibition of interracial marriages contravened the due process and equal protection clauses of the fourteenth amendment. The court overturned the decision by Virginia state court, which had sentenced Richard Loving, a white man, and Mildred Loving, a woman of color, to one year in jail for partaking in an interracial marriage, which violated the Racial Integrity Act of 1924 of Virginia. It is critical to note that at the time, intermarriage between people categorized as "colored" and those classified as "whites" was criminalized as the latter was a violation of the anti-miscegenation statutes. The Supreme Court hence aided in the eradication of such laws, which propagated racial segregation and ethnic domination.

Table 3: Dred Scott v. Sandford, 60 U.S. 393, 15 L. Ed. 691, 15 L. Ed. 2d 691 (1857).

\begin{tabular}{|r|l|}
\hline 1. & $\begin{array}{l}\text { "In the opinion of the court, the legislation and histories of the times, and the language used in the } \\
\text { Declaration of Independence, show that neither the class of persons who had been imported as slaves } \\
\text { nor their descendants, whether they had become free or not, were then acknowledged as a part of the } \\
\text { people, nor intended to be included in the general words used in that memorable instrument." }\end{array}$ \\
\hline 2. & $\begin{array}{l}\text { "They [blacks] had for more than a century before been regarded as beings of an inferior order, and } \\
\text { altogether unfit to associate with the white race either in social or political relations, and so far inferior } \\
\text { that they had no rights which the white man was bound to respect, and that the negro might justly and } \\
\text { lawfully be reduced to slavery for his benefit." }\end{array}$ \\
\hline 3. & $\begin{array}{l}\text { "We think they [Blacks] are not, and that they are not included, and were not intended to be included, } \\
\text { under the word "citizens" in the Constitution, and can, therefore, claim none of the rights and privileges } \\
\text { which that instrument provides for and secures to citizens of the United States." }\end{array}$ \\
\hline
\end{tabular}




\begin{tabular}{|c|c|}
\hline & Statements \\
\hline 4. & $\begin{array}{l}\text { "...they [Blacks] were at that time [of U.S constitution drafting] considered as a subordinate and } \\
\text { inferior class of beings who had been subjugated by the dominant race, and, whether emancipated or } \\
\text { not, yet remained subject to their authority, and had no rights or privileges but such as those who held } \\
\text { the power and the Government might choose to grant them." }\end{array}$ \\
\hline 5. & $\begin{array}{l}\text { "...the right of property in a slave is distinctly and expressly affirmed in the Constitution. The right to } \\
\text { traffic in it, like an ordinary article of merchandise and property, was granted to the citizens of the } \\
\text { United States in every State that might desire it for twenty years." }\end{array}$ \\
\hline
\end{tabular}

The Supreme Court ruled in favor of Sandford, citing that it had no jurisdiction over Scott's case, as he was not considered a citizen of the United States. As such, the black Americans could no, by any means, seek justice in the federal courts irrespective of whether they were slaves or not. Further, this ruling also held that the African Americans were not American citizens, and the United States Congress had no necessary powers to terminate slavery in the United States. Such as ruling clearly showed unequal treatment of the Americans and depicted the government's laxity in combating slavery and racial discrimination. The ruling exacerbated the existing status quo, as it was a clear indication that the whites could get away with domination and slavery. On the same note, the court further termed slaves property of the masters and argued that the Fifth Amendment protected the rights of the slave masters

Table 4: Plessy v. Ferguson, 163 U.S. 537, 16 S. Ct. 1138, 41 L. Ed. 256 (1896).

\begin{tabular}{|r|l|}
\hline 1. & $\begin{array}{l}\text { Statements } \\
\text { "Legislation is powerless to eradicate racial instincts or to abolish distinctions based upon physical } \\
\text { differences, and the attempt to do so can only result in accentuating the difficulties of the present } \\
\text { situation. }\end{array}$ \\
\hline 2. & $\begin{array}{l}\text { "Gauged by this standard, we cannot say that a law which authorizes or even requires the separation of } \\
\text { the two races in public conveyances is unreasonable, or more obnoxious to the Fourteenth Amendment } \\
\text { than the acts of Congress requiring separate schools for colored children in the District of Columbia, the } \\
\text { constitutionality of which does not seem to have been questioned, or the corresponding acts of state } \\
\text { legislatures." }\end{array}$ \\
\hline 3. & $\begin{array}{l}\text { "The argument also assumes that social prejudices may be overcome by legislation and that equal rights } \\
\text { cannot be secured to the negro except by an enforced commingling of the two races. We cannot accept } \\
\text { this proposition." }\end{array}$ \\
\hline 4. & $\begin{array}{l}\text { "...if the civil and political rights of both races be equal, one cannot be inferior to the other civilly or } \\
\text { politically. If one race be inferior to the other socially, the Constitution of the United States cannot put } \\
\text { them upon the same plane." }\end{array}$ \\
\hline
\end{tabular}

In this case, the United States Supreme Court upheld and legalized the passing of laws that promoted racial segregation. Particularly, the Supreme Court asserted that the "separate but equal" doctrine was legal and was not in violation of the Fourteenth Amendment of the U.S constitution despite the latter promoting racial segregation. It is critical to note that the Fourteenth Amendment offered equal protection of all the people, irrespective of their race. The indictment of Plessy in Plessy v. Ferguson was because the plaintiff used a train car that belonged to the whites rather than using that which was designed for the colored people. The plaintiff refused to move to the train wagons that were designated for the black people and was subsequently summoned and arraigned in court, whereby the court ruled in favor of Ferguson. Plessy's appeal in the high court did not bear any fruits, as the Supreme Court upheld the Louisiana court ruling in a 7-1 ruling, which upheld that racial segregation did not violate the United States 13tha and fourteenth amendment

Table 5: Brown v. Board of Education, 347 U.S. 483, 74 S. Ct. 686, 98 L. Ed. 873 (1954).

\begin{tabular}{|r|l|}
\hline 1. & Statements \\
\hline 2. & $\begin{array}{l}\text { "We have now announced that such segregation [the constitutionality of segregation in public } \\
\text { "We conclude that, in the field of public education, the doctrine of "separate but equal" has no place. } \\
\text { Separate educational facilities are inherently unequal." }\end{array}$ \\
\hline 3. & $\begin{array}{l}\text { "Segregation of white and colored children in public schools has a detrimental effect upon the colored } \\
\text { children. The impact is greater when it has the sanction of the law, for the policy of separating the races } \\
\text { is usually interpreted as denoting the inferiority of the negro group..." }\end{array}$ \\
\hline 4. & $\begin{array}{l}\text { "... Segregation with the sanction of law, therefore, has a tendency to [retard] the educational and mental } \\
\text { development of negro children and to deprive them of some of the benefits they would receive in a } \\
\text { racial[ly] integrated school system." }\end{array}$ \\
\hline 5. & $\begin{array}{l}\text { "Therefore, we hold that the plaintiffs and others similarly situated for whom the actions have been } \\
\text { brought are, by reason of the segregation complained of, deprived of the equal protection of the laws } \\
\text { guaranteed by the Fourteenth Amendment." }\end{array}$ \\
\hline
\end{tabular}


This was a landmark Supreme Court ruling, which played a critical role in the elimination of racial segregation in the education sector. It is critical to note that at the time, the Jim Crow laws were in effect, and states had enacted laws that supported racial segregation of the white and colored people. Racial segregation was furthered by the separate but equal doctrine, which advocated for the separation of whites and nonwhites in the use of public facilities. In this landmark ruling, the Supreme Court declared that racial segregation in any school across the United States was unconstitutional, irrespective of where the segregated schools were equal in all dimensions. In the 9-0 decision ruling, the justices found separate educational facilities to be inherently unequal. Further, the Supreme Court also found any state law that harbored racial segregation to violate the $14^{\text {th }}$ amendment of the United States constitution. It is, however, crucial to note that besides ordering the states to desegregate all the schools, it did not offer any additional insights on how to end racial segregation and discrimination.

Table 6: Ozawa v. the United States, 260 U.S. 178, 43 S. Ct. 65, 67 L. Ed. 199 (1922).

\begin{tabular}{|r|l|}
\hline 1. & Statements \\
\hline 2. & $\begin{array}{l}\text { "The appellant in the case now under consideration, however, is clearly of a race which is not } \\
\text { sharp line of demarelusion that the words "white person" means a Caucasian is not to establish a } \\
\text { naturalization, but rather a zone of more or less debatable ground outside of which, upon the one hand, } \\
\text { are those clearly eligible, and outside of which, upon the other hand, are those clearly ineligible for } \\
\text { citizenship." }\end{array}$ \\
\hline 3. & $\begin{array}{l}\text { ".We have no function in the matter other than to ascertain the will of Congress and declare it. Of } \\
\text { course, there is not implied -- either in the legislation or in our interpretation of it -- any suggestion of } \\
\text { individual unworthiness or racial inferiority." }\end{array}$ \\
\hline 4. & $\begin{array}{l}\text { "...In all of the naturalization acts from } 1790 \text { to } 1906, \text { the privilege of naturalization was confined to } \\
\text { white persons." }\end{array}$ \\
\hline
\end{tabular}

An attempt by Takeo Ozawa to become a U.S citizen was rejected by the Supreme Court. In his citizenship eligibility suit, Ozawa claimed that the Japanese Americans were whites and hence should be eligible for citizenship through naturalization. These claims were rejected by the Supreme Court based on the 1870 naturalization Act, which limited the naturalization to only African America and Whites. Among other things, the Naturalization act of 1870 stated that the naturalization press of citizenship acquisition was only applicable to "Aliens of African nativity and to persons of African descent" [21]. This implied that the laws did not allow for the naturalization of other immigrants in the United States

\section{Discussion and Conclusion}

Racial inequality is a theme that pops up when analyzing some of the landmark cases by the United States Supreme Court. This theme comes up clearly in the case of Cumming v. Richmond (1899), whereby a black family was simply denied education by the Supreme Court because the black school had been closed down and they were not allowed to get educated in a white's school. Following the end of the civil war, ethnic minorities were looking forward to recognition as well as racial equality [18]. However, the Supreme Court rulings did not seem to take into account the reconstruction amendments in the federal constitution and continued to make judgments that promoted inequality. In the case of Plessy v. Ferguson, the court had asserted that the "separate but equal" did not violate individual rights and equality and that state laws that promoted racial segregation were allowed [24].

The meaning of the "separate but equal" doctrine clearly came into light as total inequality, when the three families in Cumming v. Richmond (1899) that wanted for court intervention for their children to get education in a white school were told by the Supreme Court that the children would have to forgo education if there lacked any black school in the district of residence. If the "separate but equal standard" doctrine was meant to ensure equality, it is unclear why the Supreme Court decided to violate its own precedent. This shows that the Supreme Court at the time was more determined in offering justice to the whites, and seldom did it offer justice to the Africa Americans. This clearly indicates that the "separate but equal" concept was a tool that was used to propagate poor treatment of Africa Americans and lock the ethnic minorities out of public schools. According to Amar, the public facilities such as education centers, hospitals, and other social amenities for the blacks were poorly constructed and were incomparable to the whites' facilities [1]. As such, the separate but equal concept worked against them and weakened them, making them subjects of oppression and discrimination.

In a different ruling, The United States v. Bhagat Singh Thind, Bhagat Singh Thind was denied his request to become a United States citizen on the basis of his race; he was of Aryan descent. Despite the plaintiff having stayed in the United States for long, he was denied citizenship on the premise that he was racially ineligible for U.S citizenship. The Supreme Court, in the judgment delivered by Justice Sutherland, claimed that the Aryan blood purity had to a lesser or greater degree been tampered with, hence compromising the racial purity due to 
intermarriages that had been done between the race and other Indian races earlier on. The justices claimed that the Hindus, in general, could not be affiliated with any of the United States categories, and hence Mr. Bhagat Singh Thind could not be granted his citizenship [42].

In the United States $v$. Bhagat Singh Thind ruling, the justices focused on racial purity not just for the white race but also for other races such as the Indians, who didn't live in the United States. The fact that Thind's bloodline did not exhibit purity meant that he could not be considered a Caucasian and consequently could not be termed as a white. Further, the Supreme Court cited the Naturalization Act of 1906, which required English knowledge for an individual to be considered an American citizen. The act also barred other immigrants apart from Africa Americans from gaining American citizenship through naturalization [37]. According to Behdad, this act was flawed and created inconsistency in ensuring equality in the American justice system [5]. Essentially, the flaws in the act were corrected in the Nationality Act of 1940 and later in the Immigration Act of 1990 to ensure equality was maintained.

The theme of racial inequality also comes into light in the case of Lum v. Rice (1927), whereby the United States Supreme Court denied the Lum's family their request to attend a white school. At the time, Martha Lum's resided in Mississippi, a state that was characterized by racial segregation of the public facilities such as public schools and did not have many Chinese students to necessitate funding by the states. Hence, Martha Lum could not access education in the states and hence filed a lawsuit that found its way in the Supreme Court requesting to be allowed to attend the whites' schools [9].

Unfortunately, the Supreme Court of the United States rejected their plea. This ruling contravened federal regulations such as the fourteenth amendment. Further, it also contravened the 1924 Oriental Exclusion Act, whereby despite restricting the immigration to the United States from Asians, the Asian Americans who had been born in the United States were considered U.S citizens [29]. As a result, Martha Lum, who was of Chinese origin but born in the United States, was an American citizen. However, she was denied the chance to attend a white school simply because there were no sufficient Chinese students to warrant the Mississippi state government funding. The Supreme Court had the authority to overrule the Mississippi state constitutional provision that promoted racial segregation and discrimination under the Fourteenth amendment; however, the court did not uphold that, and worse, it denied Martha Lum her educational rights as an American citizen. This clearly showed that the Supreme Court justices were still upholding racial segregation rules propagated by individual states and least considered the federal laws that banned inequalities and racial segregation. Such a ruling was impaired and perpetrated oppression and discrimination of the ethnic minorities.

Finkelman argues that during the ruling of Dred Scott v. Sandford (1857), vast disagreements had come up between antislavery and proslavery groups, with the former advocating for slavery by the states joining the nation, while the latter categorizing slavery as illegal and that slave should be freed [16]. Graber explains that at the time of the ruling, a number of the states were shifting from slavery and laying various measures in order to restrict slave ownership and free the slaves; this is well exemplified by the establishment of the Missouri Compromise [19]. However, the ruling by the Supreme Court on the Dred Scot v. Sandford did not follow this new paradigm with respect to upholding the rights of the slaves. Chambers Jr posits that the Supreme Court justices expressed less objectivity and impartiality and were more focused on satisfying the political interests of Congress and other persons of influence, rather than serving to protect the interests of the people irrespective of their racial affiliation [11]. The ruling on the cases was an overturn of the ruling by the St. Louis County circuit court, which had earlier on ruled in favor of Scott, but Sandford appealed. In upholding the verdict, the Supreme Court, through Justice Chief Justice Taney, stated that the applicable laws, in this case, were the laws of the state in which Dred lived din when he decided to file the court case. As earlier on, it is critical to note that there was a significant difference by the states regarding the slaves, as some considered the latter as illegal while the others considered it as legal [16].

Slavery was not by any chance a choice, and hence this should not have been a limiting factor for an individual to get justice [22]. According to the Supreme Court ruling, slaves were not considered citizens, "a free negro of the African race, whose ancestors were brought to this country and sold as slaves, is not a 'citizen within the meaning of the Constitution of the United States." Strauss brings in the concept of the constitution as a living document, which can be amended with the change in sociopolitical and economic dynamics [44]. In Scott v. Sandford, this property of the constitution was undermined; this is well exemplified by the assertion of Taney that the ethnic minorities did not comprise the sovereign people that the constitution sought to protect and that the ownership of the slaves was protected ad affirmed by the constitution.

In yet another ruling, another ruling on Pace v. Alabama (1883), the United States Supreme Court showed its lack of prowess in protecting the ethnic minorities and actually perpetrated ethnic discrimination. Wallenstein posits that Section 4184 and 4189 of the Code of Alabama were specifically made to ensure the domination of the white race and subsequently suppress the black race [45]. The fact that the Alabama state then allowed such constitutional clauses to thieve clearly indicates that blacks had no rights, and they were nothing more than slaves of the whites. In this case, Purvis explains that the Supreme Court was expected to act impartially and 
render Section 4189 of the Alabama Code unconstitutional with respect to the federal laws [38].

On a different point of view, Nelson argues that the Fourteenth Amendment of the United States Constitution holds that the states should not formulate and implement laws that otherwise violate the immunities, privileges, and rights of the American citizens [35]. Further, the Fourteenth Amendment also prohibited the deprivation of any individual of liberty, life, and property, without undergoing the set judicial process [35]. The amendment stipulated that every person should realize full protection by law. The case presented clearly shows disregard for federal laws by the state of Alabama [35]. The Fourteenth Amendment was enacted in 1868, while the Pace v. Alabama case was decided in 1883. This shows that the case was decided after the enactment of the fourteenth amendment, and hence, by abridging the immunities and privileges of the Mary and Pace, the court was contravening the United States laws.

Plessy v. Ferguson (1896) is another case in the history of the American judicial system, which also shows significant negligence and contravention of the federal laws in their ruling of the Supreme Court [2]. The upholding of the "separate but equal" doctrine clearly violated the federal laws and showed disregard of the Fourteenth Amendment [24]. Further, it also showed that the justices of the Supreme Court at the time interpreted the federal laws to suit their own interests and cannot safeguard the interest of the people. By upholding the separate but equal, the Jim Crow Laws came into full effect; s racial segregation was considered legal. This landmark case created flawed preceded to all other courts of $u$ the United States, and soon after, an atmosphere of legalized dissemination emerged. This led to the oppression of the ethnic minorities and public discrimination in the following six decades, as the latter was legal. The ruling led to a pervasive spread of racial segregation in public facilities such as restrooms, theaters, hotels, restaurants, hospitals, and schools.

Baer explains that following the American civil war, various amendments had been made to the constitution, including the thirteenth, fourteenth and fifteenth amendments, in an effort to eradicated racial dissemination and encourage equality [2]. However, despite these reconstruction amendments being critical in the promotion of coexistence between dominant groups and ethnic minorities in the United States, they were informed by the majority of the states. For instance, the State of Louisiana enacted a law Withdraw Car Act (Act 111), which required separate but equal accommodation for the colored people and the whites. The main question is, if the two races were equal, why were they separated? At the state level, Judge John H. Ferguson dismissed claims by Plessy's attorney, claiming that the plaintiff had contravened the local law; the judge disregarded the federal laws, which clearly overrides the state laws in certain circumstances, such as racial discrimination [26]. The upholding of the state decision by a 7-1 majority rule in the Supreme Court shows that the majority of the injustices were more focused on promoting ethnic discrimination rather than fighting for impartiality, justice, and equality. Such an orientation indicates a lack of integrity and an impaired judicial system, which should be at the forefront of fighting for the rights of the people.

The complete deviance from the federal laws and lack of promoting social justice is well affirmed in the opinion of the only judge who dissented from the court's decision. According to Harlan, this separation of the citizens based on their skin color or race while using public transportation showed servitude that was entirely violated the equality and freedom of the $b$ people in light of the federal laws and, specifically, the 13 tha and $14^{\text {th }}$ amendment [10]. The judge further argued that upholding the "spate but equal" doctrine and subsequent conviction of Plessy could "not be justified upon any legal grounds."

Racial segregation remained prevalent more so in public families until Brown v. Board of Education (1954), when the United States Supreme Court reversed the Plessy v. Ferguson (1896) ruling and found "separate but equal inherently unequal and encouraging racial discrimination." It after this ruling that the African-American children across the various states in the United States could access education facilities that were made for the whites, and which by far were better than those of the blacks. The desegregation of the schools played a significant role in the elimination of ethnic discrimination against blacks and in promoting equality [15]. Perpetrating inequality was against the constitution and, specifically, the thirteenth and fourteenth Amendments. The thirteenth amendment was a landmark post-civil war constitutional reform that abolished involuntary servitude and slavery unless the latter was a punishment for a given crime. In the case of Cumming v. Richmond (1899), denial of the right to education to the black families yet the white families were enjoying the educational privileges was more of punishment; this contravened the thirteenth amendment.

The fourteenth amendment did grant citizenship to the U.S to the individuals naturalized or born in the United States, including the freed slaves, the majority of whom were blacks. Further, the fourteenth amendment denied nullified the state laws that did not offer equal protection of persons. In this case. In due consideration of this clause, there is no way the denial of childhood education to the black families could have been justified in the Cumming v. Richmond (1899), as this did not amount to equal protection of all persons; this was discrimination and suppression of the blacks [12]. The main question was, however, whether denying other ethnic minorities a chance to become United States citizens was justified. It is clear that the naturalization act did not serve justice, and neither did it ensure equality; it was also against the thirteenth and fourteenth amendment. It was the responsibility of the Supreme Court justices to identify the consistency in the law and come up with 
strategies to ensure justice is administered in a way that eliminates such insistencies are resolved.

Again, the naturalization act of 1906, which was a revision of the naturalization act of 1870, further did not offer any protection to the ethnic minorities and actually worsened the existing situation. This is because, in addition to barring ethnic minorities who were not of African descent citizenship by naturalization, the law further required persons to first learn how to 1 speak the English language before their admittance as citizens [20]. The fundamental question was why someone needed to speak the language of the mainstream culture in order to be considered an American citizen. Being a multiethnic nation, individuals have the right to rain their own language, and hence should not be forced to adopt a specific language. This was a great shortcoming of the federal laws and a clear indication that the congressional representatives, who were all whites, were quite determined in reducing citizenship to the nonwhites. This served to increase discrimination of the ethnic minorities, as learning the language of the mainstream culture was oppressive and an expression of dominance over the minorities [21]. The basis as to why Ozawa claim that Japanese Americans were not whites by the Supreme Court is not clear. The court did not give any profound answer as to whether the main consideration in classifying one like white or no white was skin color or race. The reliance on the impaired naturalization laws, which the supreme justices knew could not deliver justice, indicates that the entire judicial system was flawed, and the focus was perpetrating the whites' dominance and possibly eradicating the ethnic minorities.

The nullification of the Civil Rights Act of 1875 by the United States Supreme Court was one of the worst decisions in history, which depicted pure racism and faulty conception of justice [7]. Under this famous ruling, the Supreme Court argued that the Civil Rights Act of 1875, which sought to protect the legal and civil rights of the American citizens and advocate f for equal treatment of all Americans across all public facets, contravened that fourteenth and the thirteenth amendment. According to the Supreme Court judges, the thirteenth amendment still supported racial segregation and did not completely abolish slavery. By striking down the Civil Rights Act of 1875, which prohibited racial discrimination, the Supreme Court supported the oppression of ethnic minorities and lack of equality [7]. It remains a mystery why the judges thought it wise to strike down the act, which sought to establish equal treatment for all the Americans in addition to ensuring impartiality and objectivity in the delivery of justice. Further, the act did not violate the $14^{\text {th }}$ amendment as claimed, and in any case, as it sought to nullify state laws that barged immunities and privileges of the United States citizens. As a result, rather than using the minor faults in the existing 13tha and fourteen amendments to support the impaired decision, the Supreme Court injustices should have found a solution to the discrepancies and suggest possible amendments to eliminate such inconsistencies and promote the delivery of justice to the Americans

In the Scott v. Sandford, the Supreme Court argument by Taney that "It is not the province of the court to decide upon the justice or injustice, the policy or impolicy, of these laws... The duty of the court is, to interpret the instrument they have framed, with the best lights we can obtain on the subject, and to administer it as we find it..." is a clear indication of justices who lacked directional and sheer focus on the role of the Supreme Court. Finkelman refutes the argument present by Taney and explains that a major function of the Supreme Court is actually to decide on injustices and injustices and not just to interfere with the laws [16]. It is always well the duty of the Supreme Court to note whereby the laws in use are inadequate to deliver justice. This is supported by Graber, who explains that the Supreme Court is vested with the power to check the Congress and the president's actions and ascertain whether the laws passed violate the constitution [19]. Essentially, being the topmost court in use, the court rulings also set a precedent to the lower courts, and hence an impaired ruling at this level results in a ripple effect, characterized by adversities in the delivery of justice. By relying on the dysfunctional state laws that are considered legalized slaves and overturning the decision by the lower circuit court, the Supreme Court portrayed itself as infective in delivering justice. On the same point of view, Chambers Jr explains that in case of state law that is not in line with the federal constitution, the Supreme Court should notify the specific state on the same for a corrective measure to be taken [11]. As such, the actions by the justices in these cases showed a lack of clear understating regarding their roles and responsibilities as Supreme Court justices.

On a different note, Wallenstein holds that the justice in Pace v. Alabama interpreted the material facts to the advantage of the state of Alabama and to the disadvantage of the plaintiffs, who, in this case, had violated the intermarriage laws [45]. In the ruling, the justices argue that "...Whatever discrimination is made in the punishment prescribed in the two sections is directed against the offense designated and not against the person of any particular color or race." Wallenstein criticizes this assertion based on why it was wrong in the first place to intermarry [45]. Analytically, the indicting of individuals for interracial fornication can be viewed from two perspectives; while there was equal administration of the punishment for the parties involved, for the whites, it served to deter other whites from the same, while for the blacks, it was made to deter interaction with the whites and also intimidate them by showing them that they did not, by any means match the whites standard and could not by any chance intermarry with them. Further, owing to the fact that the whites were and still are the dominant group, the law observed to the disadvantage of the backs, isolating and suppressing them while trying to strive and survive in the whites-dominated culture.

The failure of the court to answer the question of why intermarriage was considered working and 
punishable clearly showed that the justices were not concerned about delivering justice to all the Americans but rather supporting the state laws and congressmen, who seldom cared for the rights of the ethnic minorities. The Supreme Court further did not question the existence of Section 4189 of the Alabama Code, which by all means contravened the fourteen amendments by offering unequal treatment of the black people; the reason as to why the intermarriage was not supported is because the blacks were looked down on, and were not perceived to match the whites by all means [39]. If the blacks were considered equal to the whites, intermarriage and interactions would not have been banned.

The cost of impaired judgment by the Supreme Court has a ripple effect on the administration of justice across the entire United States. The ruling of Pace v. Alabama acted as critical precedence in the American judicial system for 81 years, until $\mathrm{w}$ it was challenged in McLaughlin v. Florida (1964) and ultimately overturned in Loving $v$. Virginia (1967), which henceforth nullified all any state law that banned in marriage and interaction between people of different races. The decision in Loving v. Virginia (1967) clearly shows what should have been done in Pace v. Alabama (1883).

According to Baer, despite these amendments, which were clearly oriented towards making significant strides in recognizing ethnic minorities as part of the American society and promoting equality, the ethnic minorities and, specifically, African American continued undergoing pervasive discrimination until the mid-20 $0^{\text {th }}$ century, when a significant decline in such cases was realized [2]. Nevertheless, to date, cases of racial and ethnic profiling are still reported, as well as discrimination on the basis of skin color [30]. While the American judicial system has played a significant role in promoting equality and post-civil war reconstruction, the same judicial system played a significant role in harboring racism in the United States, through decisions in various cases that showed complete neglect for the prevailing federal laws and which cultivated an atmosphere of racial inequalities and oppression of ethnic minorities.

\section{References}

[1] Amar, A. R. (2011). Plessy v. Ferguson and the Anti-Canon. Pepp. L. Rev., 39, 75.

[2] Baer, J. A. (2018). Equality under the constitution: reclaiming the fourteenth amendment. Cornell University Press.

[3] Babbie, E. (2011). The basics of social research. $5^{\text {th }}$ ed. Wadsworth, Cengage Learning.

[4] Bean, F. D., \& Lee, J. (2009). Plus ça change...? Multiraciality and the dynamics of race relations in the United States. Journal of Social Issues, 65(1), 205-219.

[5] Behdad, A. (1997). Nationalism and immigration to the United States. Diaspora: A Journal of Transnational Studies, 6(2), 155-178.

[6] Bell, D. (2000). Brown v. Board of Education: Forty-five years after the fact. Ohio NUL Rev., $26,171$.

[7] Bracey, C. A., \& Foster, C. J. (2018). Gale Researcher Guide for: The Civil Rights Act of 1866. Gale, Cengage Learning.

[8] Carter, D. T. (1997). Let Justice Be Done: Public Passion and Judicial Courage in Modern Alabama. Cumb. L. Rev., 28, 553.

[9] Casas, M. (2006). A Historical Analysis of the United States Supreme Court and Its Adjudication of Gong Lum v. Rice (1927) and Keyes v. Denver School District No. 1 (1973). Journal of Thought, 41(4), 83-102.

[10] Cases, S. H. (2013). Separate-but-Equal.

[11] Chambers Jr, H. L. (2007). Dred Scott: Tiered Citizenship and Tiered Personhood. Chi.-Kent L. Rev., 82, 209.

[12] Connally, C. E. (2000). Justice Harlan's "Great Betrayal”? A Reconsideration of Cumming v. Richmond County Board of Education. Journal of Supreme Court History, 25(1), 72-92.

[13] Eisenberg, T. (1979). State Law in Federal Civil Rights Cases: The Proper Scope of Section 1988. U. Pa. L. Rev., $128,499$.

[14]Farber, D. A. (2011). A Fatal Loss of Balance: Dred Scott Revisited. Pepp. L. Rev., 39, 13.

[15]Fife, B. L. (1992). Desegregation in American Schools: Comparative Intervention Strategies. Praeger Publishers, Greenwood Publishing Group, Inc., 88 Post Road West, Box 5007, Westport, CT 06881.

[16] Finkelman, P. (2008). Was Dred Scott Correctly Decided-An Expert Report for the Defendant? Lewis \& Clark L. Rev., 12, 1219.

[17] Golub, M. (2005). Plessy as "passing": Judicial responses to ambiguously raced bodies in Plessy v. Ferguson. Law \& Society Review, 39(3), 563-600.

[18] Gordon, R. J. (2017). The rise and fall of American growth: The US standard of living since the civil war (Vol. 70). Princeton University Press.

[19] Graber, M. A. (2006). Dred Scott and the problem of constitutional evil. Cambridge University Press.

[20] Guttentag, L. (2013). The Forgotten Equality Norm in Immigration Preemption: Discrimination, Harassment, and the Civil Rights Act of 1870. Immigr. \& Nat'lity L. Rev., 34, 71.

[21] Han, H. (2016). To Make an American. Pennsylvania Legacies, 16(2), 3-5. 
[22]Huebner, T. S. (2010). Roger B. Taney and the Slavery Issue: Looking beyond-and before-Dred Scott. The Journal of American History, 97(1), 17-38.

[23] Ichioka, Y. (1977). The Early Japanese Immigrant Quest for Citizenship: The Background of the 1922 Ozawa Case. Amerasia Journal, 4(2), 1-22.

[24] Johnson, M. (2017). Separate but (Un) Equal: Why Institutionalized Anti-Racism Is the Answer to the Never-Ending Cycle of Plessy v. Ferguson. U. Rich. L. Rev., 52, 327.

[25] Katz, E. D. (2015). Enforcing the Fifteenth Amendment. The Oxford Handbook of the US Constitution, 365.

[26] Kelley, B. M. (2010). Right to ride: Streetcar Boycotts and African American citizenship in the era of Plessy v. Ferguson. Univ of North Carolina Press.

[27]Lado, M. L. E. (1994). A Question of Justice: African-American Legal Perspectives on the 1883 Civil Rights Cases. Chi.-Kent L. Rev., 70, 1123.

[28] Ladson-Billings, G., \& Tate, W. F. (1995). Toward a critical race theory of education. Teachers college record, $97(1), 47$.

[29]Lee, E. (2002). The Chinese exclusion example: Race, immigration, and American gatekeeping, 18821924. Journal of American Ethnic History, 36-62.

[30] Maira, S. (2016). "Racial Profiling" in the War on Terror Cultural Citizenship and South Asian Muslim Youth in the United States. Contemporary Asian America: A Multidisciplinary Reader, 444.

[31] Mayeux, S. (2013). Ineffective Assistance of Counsel Before Powell v. Alabama: Lessons from History for the Future of the Right to Counsel. Iowa L. Rev., 99, 2161.

[32] Medley, K. M. (2012). We as freemen: Plessy v. Ferguson. Pelican Publishing.

[33] Miller, J., \& Garran, A. M. (2017). Racism in the United States: Implications for the helping professions. Springer Publishing Company.

[34] Nakanishi, D. T. (1993). Surviving Democracy's "Mistake": Japanese Americans \& the Enduring Legacy of Executive Order 9066. Amerasia Journal, 19(1), 7-35.

[35] Nelson, W. E. (2009). The Fourteenth Amendment: from political principle to Judicial doctrine. Harvard University Press.

[36] Novkov, J. (2009). Racial union: Law, intimacy, and the white state in Alabama, 1865-1954. University of Michigan Press.

[37] Ovando, C. J. (2003). Bilingual education in the United States: Historical development and current issues. Bilingual research journal, 27(1), 1-24.

[38] Purvis, D. E. (2007). The Right to Contract: Use of Domestic Partnership as a Strategic Alternative to the Right to Marry Same-Sex Partners. Women's RTS. L. Rep., 28, 145.

[39] Richter, J. W. (2015). Alabama's Anti-Miscegenation Statutes. Alabama Review, 68(4), 345-365.

[40] Schneider, D. (2001). Naturalization and United States citizenship in two periods of mass migration: 18941930, 1965-2000. Journal of American Ethnic History, 50-82.

[41] Segal, D. R. (1994). National Security and Democracy in the United States. Armed Forces \& Society, 20(3), 375-393.

[42] Skop, E., \& Li, W. (2010). Diaspora in the United States: Chinese and Indians compared. Journal of Chinese Overseas, 6(2), 286-310.

[43] Snow, J. (2004). The civilization of white men: The race of the Hindu in the United States v. Bhagat Singh Thind. Race, nation, and religion in the Americas, 259-280.

[44] Strauss, D. A. (2010). The living constitution. Oxford University Press.

[45] Wallenstein, P. (1994). Race, Marriage, and the Law of Freedom: Alabama and Virginia 1860s-1960s. Chi.Kent L. Rev., 70, 371.

[46] Weaver, V. W. (1969). The Failure of Civil Rights 1875-1883 and Its Repercussions. The Journal of Negro History, 54(4), 368-382.

[47] White, G. E. (2015). The lost episode of Gong Lum v. Rice. Green Bag, 18(2), 191-205.

[48] De Tocqueville, A. (2003). Democracy in america (Vol. 10). Regnery Publishing. 